\title{
Open Textbooks: A Balance Between Empowerment and Disruption
}

\author{
Anne Algers ${ }^{1}$ (D) \\ Published online: 23 November 2019 \\ (c) The Author(s) 2019
}

\begin{abstract}
The use of open textbooks in universities is according to some organisations changing the higher education landscape and is promising for the mainstream adoption of OER. The aim of this paper is to analyse authors' views of agency and empowerment when they plan, create and reflect on their open textbooks, their teaching and students' learning. Another aim is to analyse the ways in which knowledge supports authors' creation of open textbooks and tensions inherent in this practice. This qualitative study used a modified version of a validated questionnaire for $1 \mathrm{~h}$ long semi-structured interviews with four interviewees, conducted over 4 days. The data from the interviews were analysed in three steps combining two coding structures, for self-regulated learning and levels of contradictions. The results suggest that the four authors engendered a sense of relational agency in the creation process. They indicated that they valued openness and the pedagogical project itself by highlighting both teachers' and learners' perception of agency and empowerment. The data also support the authors' concerns about the disruptive nature of open textbooks regarding stability versus adaptation and data ownership as it relates to use of learning analytics and commercial interests, indicating considerable contradictions in open textbook practices.
\end{abstract}

Keywords Open textbooks · Open educational practice (OEP) - Higher education · Agency $\cdot$ Cultural historical activity theory (CHAT)

\section{Introduction}

Open textbooks (OT) are part of the broader open educational resources (OER) movement. They were identified in the Horizon Report (Johnson et al. 2010) as an important component of the rapidly progressing adoption of openness in higher education.

The currently most encompassing definition of Open Textbooks is by Wikipedia and reads as follows:

Anne Algers

Anne.Algers@gu.se

1 Department of Education, Communication and Learning, Gothenburg University, Pedagogen A, Västra Hamngatan 25, 40530 Gothenburg, Sweden 
An Open Textbook is a textbook licensed under an open copyright license and made available online to be freely used by students, teachers and members of the public. Many open textbooks are distributed in either print, e-book, or audio formats that may be downloaded or purchased at little or no cost (Learn More About Open Textbooks, the Student PIRGs, 2019).

The purpose of open textbooks is education and therefore knowledge is organized to facilitate the user's learning but the incentives to create open textbooks go beyond making the subject matter more affordable for students (Wiley et al. 2012), e.g. to make the textbooks available for a broader community and to provide creators and adaptors with the ability to reuse, remix and redistribute the material in order to customize it for their courses. Thus, teachers may use and remix open textbooks to assemble information to meet their instructional needs (Baker and Hood 2011). Furthermore, it is argued that open textbooks enable learners to design their own learning paths, to use multimodality and, sometimes, to annotate or change the content (McAndrew and Farrow 2013).

The change of focus from OER to open educational practices (OEP) is a recognition of the socio-cultural learning theories that emphasize the influence of social and cultural experiences. Or put in other words, about using the technologies that provide infrastructures for learning cultures based on interchanges among users for the development of mental processes (Hood and Littlejohn 2017; Säljö 2012). Based on various definitions in the literature, OEP is an empowerment process for both the educators, by giving them greater control of which resources and how they use them (Farrow 2017), and the learners, by allowing them to interact, collaborate, create, and use materials for their learning (Kanwar et al. 2010).

Hood and Littlejohn have posited that OER and OEP can make teaching and learning more collaborative and relevant, reduce costs for students and reach new target groups (Hood and Littlejohn 2017). The adoption of OER has been a response to educational challenges, such as equity in the Global South, and is a strategic priority within the European Union (Ecorys and Bertelsmann Stiftung 2015; European Commission 2013) and has been supported by intergovernmental agencies, such as UNESCO and the Commonwealth of Learning, and philanthropic organizations, such as the Hewlett Foundation (Arinto et al. 2017).

Jhangiani et al. (2016) described various approaches to open textbook development and analysed the incentives of the authors. They concluded that higher education teachers scoring high on the personality trait of 'openness to experience' were more likely to engage in OEP. Other findings have confirmed that 'willingness to share knowledge and expertise is an important factor to support self-regulation and learning across sites' (Edwards 2010, p. 10). Edwards is drawing on the work of Vygotsky and social-cultural historical activity (CHAT) as developed by Engeström (1987) to bring new understanding of learning and tensions in collaborative practices leading to relational agency and collective and distributed knowledge (Edwards 2010). This emphasis on multi-agency among learners and teachers align with the theory of self-regulated learning (Zimmerman 2000) that refers to autonomy and control over one's own learning.

The purpose of this study was to explore faculty creation and use of open text-books at British Columbia post-secondary institutions. The aim was to investigate open textbook authors' views of agency and empowerment when they plan, create, and reflect on their open textbooks, their teaching and their students' learning. Another aim was to identify various types of learning and contradictions in open textbook practices. The research questions were: (1) How do authors plan, implement and reflect on the creation of OT? (2) Do OTs enable self-regulated learning for teachers and learners? and (3) How strong are the contradictions in OT practices? 


\section{Theoretical Framework}

Self-regulated learning describes a process of taking control of and evaluating one's own learning and behaviour. Thus, a learner is self-reliant when he or she has developed 'selfgenerated thoughts, feelings and actions that are planned and cyclically adapted to the attainment of personal goals', and this can be recognised and measured in three phases; forethought, performance and self-reflection (Zimmerman 2000, p. 14).

Using a factor analysis, six knowledge types for self-regulated learning have recently been identified as supporting the expansion of OEP. They are (1) general conceptual/theoretical knowledge, (2) specific conceptual/theoretical knowledge, (3) practical/experiential knowledge, (4) self-regulative knowledge, (5) socio-cultural community-based knowledge and (6) socio-cultural workplace-based knowledge (Hood and Littlejohn 2017). The result support the premises that teachers require access to multiple types of knowledge and are able to move fluidly between them in order to become open education practitioners.

In order to get a deeper analysis of the motives and inner tensions behind the authors activities, the cultural historical activity theory (CHAT) was used as a lens to analyse tensions and contradictions, especially in activities characterised by information technology (IT)-based social and participatory practices (Engeström and Sannino 2010). Contradictions are not always easy to identify, rather they become recognized through people's articulation of tensions and contradictions (Engeström and Sannino 2011). CHAT is a theoretical framework based on the idea that people's activities' are driven by their intentions with their activities. It addresses the relationship between actors and their motives and concerns, and it gives the activities a special direction (Engeström 1987). This means that (1) humans act collectively, learn by doing and communicating in and through their actions; (2) humans make, employ and adapt tools or instruments to learn and to communicate; and (3) a community is central to the process of making and interpreting meaning and, thus, to all forms of learning, communicating and acting (Kaptelinin and Nardi 2006). When the CHAT is used to analyse the learning approaches related to the authoring of open textbooks, many actors are involved. A number of competences are needed for identifying the tools to enable learning, to adapt content to societal rules (e.g., legislation and rules in higher education), to consider the power relations among the actors (which relates to the division of labour), to identify learning goals and to gather the related content.

The contradictions between actors and the tools they use may facilitate learning and change as a result of the activities. However, to which degree the contradictions affect the actors depend on the reasons for these contradictions. Kaptelinin and Nardi (2006) emphasised that when the conditions for operations are frustrated, humans most often do not notice. When the goals for actions are frustrated, humans create new goals; however, when the motives for activities are frustrated, people become emotionally involved (Kaptelinin and Nardi 2006). Engeström and Sannino (2011) argue along the same lines, that contradictions are best manifested through four levels of contradictions, based on their severity: dilemmas (lowest level of severity), conflicts, critical conflicts and double binds (highest level of severity). Dilemmas are easier to resolve than conflicts. Critical conflicts involve contradictory motives and require the negotiation of new meaning. Double binds are situations with equally unacceptable alternatives that sometimes involve emotions, thus requiring collective effort (Engeström and Sannino 2011).

One of the most promising open-textbook projects is the B.C. (British Columbia) Open Textbook Project (https://open.bccampus.ca), which began in 2012 with the goal of making post-secondary education in British Columbia more accessible by reducing 
student costs through the creation and use of openly licensed textbooks. The project is administered by BC campus and funded by the Hewlett Foundation and the British Columbia Ministry of Advanced Education (Bliss 2017).

\section{Methodology}

Four open textbooks authors were interviewed in Vancouver for four consecutive days April 2017. The authors were on the researcher's request for this study, selected by the open education team at the $\mathrm{BC}$ campus to include open textbook projects with a variety of processes, goals and topics. All of the authors were professors in various subjects such as literature, history, geography and education and the authors were taking part in informed consent.

Using a modified version of a validated questionnaire (Fontana et al. 2015), the interviewer guided the discussion so that a number of specific topics were discussed. The original questionnaire was used for measuring self-regulated learning in the workplace and was validated in a study by Hood and Littlejohn (2017). This questionnaire was modified in two ways: (1) to address open textbooks specifically rather than OER in general and (2) to address how professionals in higher education rather than in business use technology to support their self-regulated learning. The survey instrument comprised three scales: their current engagement with OT, the influence of the workplace context on their learning, and the final scale measured the educators' ability to self-regulate their professional learning when engaging with OT. See interview guide attached in "Appendix 1".

The interviews were audiotaped. Each was about $1 \mathrm{~h}$. They were transcribed in their entirety and these documents included who spoke, what was said, and, in some cases, how it was said. The data were categorised by the author of this article according to the research questions. The first round of analysis focused individuals' expression of their knowledge experiences and how the authors created the open textbooks.

The second round of analysis used typical linguistic cues to analyse data for manifestations of four different levels of contradictions (Engeström and Sannino 2011). The linguistic cues for the manifestation of a dilemma included statements such as: 'yes, but', 'on the one hand ... on the other hand', 'I didn't mean that', 'I actually meant' or the reformulation of a concept. The cues for a conflict included contentions as: 'no', 'I disagree' and 'this is not true'. The linguistic cues for a critical conflict were more personal, emotional and moral. Finally, the cues for a double bind were an expression of helplessness or 'we have to' as an indication of the need for a joint effort. Seventy-seven (77) citations were identified on the basis of these linguistic cues, and these citations were subsequently analysed in the third round through the Hood and Littlejohn (2017) framework for the manifestations of self-regulated learning. Previous research has shown that the combination of methods from studies on "manifestations of contradictions" and "self-regulated learning" can be used to analyse open educational practices (Kaatrakoski et al. 2017).

The three-step qualitative analysis is presented in detail in the Results section. Citations of relevance were identified, and each excerpt was treated as a natural unit of analysis, complementing the interpretative thematic analysis. 


\section{Results}

First, the results from the first round of analysis about the three phases in the authors' selfregulated learning (forethought, performance and self-reflection) during the creation process are presented. Second, the results related to the linguistic cues were used to identify contradictions and third, the results about the six types of learning supporting the authors engagement with and learning from OT are presented.

\subsection{Three Phases in Authors' Creation Process}

The authors' responses about their general use of OER and the sense of agency and empowerment when they planned, created and reflected upon the authoring of the open textbook showed that all the authors had an advanced level of OER use at the time of the interview. However, two of them did not have a high awareness of OER when they started creating the open textbook. One of them stated:

I didn't even know that I was doing something that was a 'thing'... I had heard about Creative Commons; so, I understood the difference between copy-right and Creative Commons, I understood 'domain', I understood a 'high textbook cost', but I had no connection to the OER community ... So, I started in isolation and once I started getting interested in OEP I realized: Oh! There is a whole world of people doing this kind of stuff.

This excerpt can be interpreted as an articulation of the first of the three phases in SRL - the forethought phase. The author set specific proximal goals and has high beliefs in having the personal capability to reach these goals.

The authors used a variety of creation processes. One author had created the open textbook mostly alone. He based the creation process on blog posts in combination with online dialogue with peers. Another author created it in a Book Sprint process with colleagues. The remaining two authors had created their open textbooks together with students, who were able to have a greater degree of agency as the process evolved. One of them included videos and reflected on this experiment:

Students say there is the narrative by the main author but it's not only his voice there are many voices ... and the instructors should feel confident to add their own voices if they want to add their own stuff or wanna challenge what somebody is saying. They can do that - they can engage in the debate and they can actually even imbed students debates in the textbook.

The performance phase is divided in two parts; self-control and self-observation. The self-control refers to the deployment of a specific strategy, in this case the creation processes, decided during the forethought phase. Self-observation refers to self-experimentation as indicated by the excerpt above.

One author described the creation process as a pedagogical endeavour like this:

Students were super excited that the book was free, but they weren't excited when they started using it because it lacked a lot additional material that they were used to - like illustrations, maps and instructions, and introductions. So that was when we started to use the current students in the course to build out the textbook with the things that they found were missing, and they got really excited about contributing to a book. So, what started out as a cost replacement model ended up being much more a pedagogic success story. 
This excerpt is an articulation of the third phase; self-reflection. It refers to comparisons of self-observed performances against a common standard and involves causal attribution, which is a discussion about the cause of one's mistakes or successes.

\subsection{Contradictions in Open Textbook Practices}

Second, the data were analysed using the typical linguistic cues for manifestations of the four levels of contradictions. This resulted in the identification of a total of 77 quotations (see Table 1).

Dilemmas were most frequently occurring, whereas conflicts and critical conflicts were less common. In this study, surprisingly, many (12) incidents of the most severe form of contradictions, double bind, were identified. It became evident during the data analysis that although the authors were engaged with the open textbooks in a variety of ways, the differences in approaches among authors did not seem to influence the manifestations of the contradictions. Consequently, the data from all of the interviewees were further analysed collectively.

The dilemmas were related to open textbooks' being disruptive to the use of traditional textbooks and having various functions and levels of complexity. One of the authors said that everything would change when an open textbook advocate walked into the room with a printed version of the textbook: "People would say, 'Oh, it's a real text textbook! It's not just a website." Another expression of a dilemma was the view on and the need for involving students in open education: "We don't want to teach and check but to get students involved in creation of knowledge. If you don't involve students in the content, they are not connecting". One author expressed the dilemma related to the difficulty in knowing whether learners using OT had merely accessed the book, whether they had used it for learning or whether it had had any effect on their learning.

The quotations labelled as conflicts were characterised as either criticising the concept of openness in open textbooks or focusing on the data ownership problems that associated with learning analytics (LA). The concern was that the data not be misused but, rather, be pedagogical tools for users. One of the authors referred to the conflict in the open education movement between definitions of openness, with 'access' used by computer scientists and 'participation' used by educational scientists. Referring to cultural differences, the same author criticised the American view on openness as access to education 'dominated by private or commercial education' and compared it to openness as a 'pedagogical think' in the UK-'which is a much broader definition [than access to education]'. One of the authors also referred to an argument with $\mathrm{BC}$ campus about using a comment box for the book: a disagreement about the need for a comment box for informal learners and the need to continuously answer those comments.

The critical conflicts expressed by the authors related to feelings of guilt or violation. The quotations were manifestations of the disruptive nature of openness to traditional

Table 1 Distribution of coded quotations of manifestations of contradictions, from lowest (dilemma) to highest level of contradictions (double bind)

\begin{tabular}{lcllll}
\hline & Dilemma & Conflict & $\begin{array}{l}\text { Critical } \\
\text { conflict }\end{array}$ & Double bind & Total \\
\hline Author A & 12 & 4 & 2 & 5 & 23 \\
Author B & 9 & 3 & 3 & 2 & 17 \\
Author C & 16 & 1 & 2 & 5 & 24 \\
Author D & 11 & 1 & 1 & 0 & 13 \\
Total & 48 & 9 & 8 & 12 & 77 \\
\hline
\end{tabular}


higher education. One author expressed a sense of guilt for having asked 'friends' to write reviews because, according to this author, there was no system for receiving independent reviews. Another author expressed guilt for not always being able to find non-proprietary software to imbed in the open textbook. Some authors touched upon the problem of locating OER in repositories, which were not always easy to find, and negotiating new meaning, such as finding new systems for making OER and open textbooks searchable. In addition, the problem of stability versus the adaptation of resources was mentioned. One author said:

But once the book is out there, there will be hundreds of 2.0 versions of the textbook ... So, I see it very much as a dynamic learning tool ... That's the more exciting part of that. It's not what I have been writing.

The excerpt above relates to both accuracy of the information communicated by the resource, which the author loses control of when it's open, and relevance, which has to be assessed in the context between a specific user and a specific resource, that gives the resource legitimacy.

The authors exhibited double bind when facing equally unacceptable alternatives. This resulted in either expressions of helplessness or suggestions for a practical transformation. One author argued for a transformation of teaching practices in favour of involving students in gathering information for the open textbook:

Sometimes content is number one of what your students need. But for me, sometimes, its number two. And the experience of the building [of knowledge] is actually more valuable than the specifics of that content.

Another author had rhetorical questions about LA and the way that the algorithms are written and can be misused:

What kind of decisions are being embedded in those algorithms? The obvious example is that they are using LA to predict students' success before they enroll ... My worry is that that they are going to screen out all the students who they feel don't have a chance of surviving. And what kind of education policy is that?

\subsection{Self-regulated Learning in Open Textbook Practices}

In a third round of data analysis, the six types of knowledge supporting adult educators' engagement with and learning from OER identified by Hood and Littlejohn (2017) were used (see Table 2). In their study, they found no reason for handling the individual interviewees separately; Likewise, there was no reason to handle the authors in this study separately. The number of quotations has been aggregated into a combined table of the two coding systems in Table 3. "Appendix 2" is a compilation of excerpts from each coding type.

Type 1 did not occur frequently in the interviews. This is general conceptual/theoretical knowledge, which is most beneficial for users in the initial stages of their engagement with OER. This was not the case here since the authors at the time of the interviews were advanced users of OER. Type 2 is context-specific theoretical knowledge, but again, the authors were relatively confident and did not talk much about theoretical knowledge that is specific to and situated within the contexts of their work.

Type 3 is practical/experiential learning, which was indicated more frequently in the quotations. This is related to the creation of open textbooks and the application 
Table 2 Distribution of same quotations of manifestations of self-regulated learning (After Hood and Littlejohn 2017)
Table 3 Distribution of number of quotations of manifestations of contradictions and self-regulated learning

\begin{tabular}{llc}
\hline & Knowledge type/code & Number \\
\hline Type 1 & General conceptual/theoretical knowledge & 5 \\
Type 2 & Specific conceptual/theoretical knowledge & 8 \\
Type 3 & Practical/experiential knowledge & 16 \\
Type 4 & Self-regulative knowledge & 17 \\
Type 5 & Socio-cultural knowledge (community based) & 17 \\
Type 6 & Socio-cultural knowledge (workplace based) & 14 \\
Total & & 77 \\
\hline
\end{tabular}

\begin{tabular}{lcllcc}
\hline & Dilemma & Conflict & $\begin{array}{c}\text { Critical } \\
\text { conflict }\end{array}$ & Double bind & Total \\
\hline Type 1 & 3 & 2 & 0 & 0 & 5 \\
Type 2 & 7 & 0 & 1 & 0 & 8 \\
Type 3 & 8 & 3 & 2 & 3 & 16 \\
Type 4 & 13 & 1 & 2 & 1 & 17 \\
Type 5 & 7 & 1 & 1 & 8 & 17 \\
Type 6 & 10 & 2 & 2 & 0 & 14 \\
Total & 48 & 9 & 8 & 12 & 77 \\
\hline
\end{tabular}

of theoretical/conceptual knowledge to practice, which was one of the focuses of the interview. Type 4, self-regulative knowledge, appeared rather frequently, supporting the authors' understanding of and reflection on the value of the open textbook for teachers and learners. Type 5, socio-cultural knowledge (community-based), was also seen frequently. The quotations indicate that the authors identified the importance of a sociocultural approach for colleagues and students to expand their practices. One author explained:

I do think students realize that knowledge is not coming from a closed resource but something that we as a community can build and build better. I think that the younger generation... I think they have a better idea of collaborate approaches...I think they understand that they can build better together, whereas I think my generation, or maybe the one before me, was really focused on the individual contribution.

Type 6, socio cultural knowledge (workplace based), also appeared rather frequently. This relates to identifying the role of workplace structures in shaping knowledge construction.

\section{Discussion}

\subsection{Authors Creation Process}

The first round of analysis indicated that the four authors had different incentives and goals related to a strong sense of agency. From the interviews, the three phases in self-regulated learning could be identified; forethought phase, performance phase and self-reflection 
phase (Zimmerman 2000). They had divergent self-regulatory processes or beliefs, such as goal setting, strategy use, and self-evaluation, but their personal initiative, endurance, and adoptive skills made them self-regulated scholars.

A variety of creation processes were applied-from being based on blogs, including dialogue with peers, to collaborative creation with peers or collaborative creation among students, with decreased scaffolding by the author. However, all authors expressed a sense of the creation process being an experience drawing on socio-cultural theories and putting ideas into action through 'learning by designing' that enhanced their knowledge and their ability to apply it in realistic settings, as described by Karunanayaka and Naidu (2018).

In order to better understand the authors' experiences and motives, two theoretical lenses were combined in this study: the six knowledge typologies related to open educational practices (Hood and Littlejohn 2017) and the four manifestations of contradictions identified by Engeström and Sannino (2011).

\subsection{Contradictions in Open Textbook Practices}

It is evident that in the cases of contradictions related to theoretical/conceptual knowledge, the contradictions were weak (most often coded as dilemmas) and thus did not refer to agonised mental stages but to aspects of socially shared beliefs (Engeström and Sannino 2011).

The contradictions related to practical/experiential knowledge related to OEP were more severe. OEP is also known as being disruptive, leading to changes in the higher education teaching traditions and success requires expertise, time, commitment and institutional support (e.g. Camilleri et al. 2014). The authors were very aware of this and they recognised the importance of an institutional framework for quality assurance and technical support from the B.C. Open Textbook project.

The contradictions involved in the authors' self-regulative knowledge were weak; almost entirely on the dilemma level. These contradictions were related to the evaluation of their own actions and is expected to be an effect of the fact that the authors were rather experienced. More serious are contradictions identified in relation to community-based activities. This was also the knowledge typology related to the most critical conflicts. The authors had concerns related to open textbooks' continually being in flux and having a multitude of versions and authors, as previously argued by Camilleri et al. (2014). The authors discussed peer reviews of open textbooks as snapshots of the quality of the books, indicating that this has been discussed as problematic before (McAndrew and Farrow 2013).

They were also worried about the black boxing of learning analytics, which may be used to track the individual use of open textbooks. Learning analytics, which use the data produced during teaching and learning with digital formats, provide a way to understand and to improve learning and the learning environment (Van Leeuwen et al. 2015). This kind of formative analysis can be conceptualised as analytics for learning; however, learning analytics may also be used in ways that can be regarded as the analytics of learning. This way of using learning analytics can be seen as being intrusive or violating student privacy. In addition, some providers of learning analytics tools are commercial, and this may add to the ethical dilemma (Pardo and Siemens 2014). Säljö (2012) discussed the phenomenon of digital tools' black boxing processing capacities because users often have little knowledge about its technical design or the programming that goes into it. On the other hand, he asked: "How far in terms of white boxing do we need to go? These questions are difficult to answer since understanding is relative to the task one wants to perform" (p. 14). 
The issues raised about socio-cultural knowledge for specific workplace settings were mostly structural and related to resources and time. The authors were interested in using learning analytics to improve their teaching. Two of the four authors had tried to do so, but none could identify ways to use it for improving their teaching or the quality of the open textbook. The authors were very much aware of the risks related to the misuse of learning analytics and data ownership. They articulated their concerns for the students. Their views are in line with the results of the latest research by scholars such as Chatti et al. (2017) on the need for more research on open learning analytics.

\subsection{Self-regulated Learning in Open Textbook Practices}

The data support the findings by Hood and Littlejohn (2017) that authors possess multiple types of knowledge and move fluidly between the knowledge typologies. The authors found the technological aspects of the creation process straightforward and argued that the B.C. Open Textbook Project assisted with all the help they needed. The data included only a few indications of conceptual/theoretical learning, which for example can be about the legal frameworks, the quality assessment and hosting of OER. This reflects the fact that the authors are advanced open education practitioners (Hood and Littlejohn 2017) and that the interviewer was steering the discussion in the direction of a more complex understanding of OEP.

The knowledge Type 4, self-regulative knowledge, appeared rather frequently. It is the metacognitive and reflective skills that learners use to monitor and evaluate their own actions and to make sense of their knowledge. Hood and Littlejohn (2017) argue that self-regulative knowledge enables authors to shift their engagement with OER from a supplementary component of their practice to an integral element of practice, and thus support the authors' understanding of and reflection on the value of the open textbook for teachers and learners.

The knowledge type 5 and 6, socio-cultural knowledge (community-based and workplace-based) were also rather common indicating that authors found the socio-cultural approach important, not only as a supporting network but as a community of colleagues, peers and students sharing the same interests. The OT may be seen both as a matter of fact and as a matter of concern; a critical attitude that Latour (2005) suggested for academia-one that neither takes the fairy-position nor the fact-position. The authors in this study regarded their OT as a matter of both facts and concern that is giving raise to questions, challenges and new ways of thinking.

The authors were very enthusiastic when they reflected on their pedagogical achievements. They found the discussion of access in open education too limited and wanted to highlight the pedagogical benefits of openness for empowering students (Kanwar et al. 2010) and allowing them to be a part of the knowledge creation process (Freire 2000). The issue of participation, rather than access, links to the theory of expansive learning, which is about learning something that does not yet exist (Engeström and Sannino 2010). Thus, in line with the expansive learning theory, the open textbook projects allowed the actors to construct new content that was interwoven with the acquisition of the requisite knowledge.

One of the authors points in a quote to the fact that open textbooks can include multiple modes of communication and meaning making. This kind of multimodality looks beyond the written text as a holy grail and Kress (2009) argues that this is the normal state of human communication.

The data also support the idea of open practices being a social culture (in this case involving students and peers) creating relational agency and collective and distributed 
knowledge (Edwards 2010) as well as satisfaction for teaching staff in an otherwise solitary profession (Iiyoshi and Kumar 2008).

\subsection{Conclusions and Practical Implications}

This study shows how teachers may enact agency by aligning the open textbooks with their instructional needs and involving students and peers in the use and remix of open textbooks, which gives empowerment beyond access to educational material for free.

From this study it even became evident that open textbooks may be tools for enabling teachers to self-regulate their learning through the creation process. The authors of open textbooks in this study had personal initiative, endurance, and adoptive skills. Further, the authors had a strong belief that open textbooks can also be tools for students' self-regulated learning, as exemplified with collaborative approaches, which is closely related to their performance (Zimmerman 2000).

Based on the analysis of manifested contradictions, the study indicates that there are both weak and strong contradictions in open textbook practices. One example is issues related to the stability of an open textbook (that an author loses control of the book) versus adaptation (that the book can be found in many different versions). Another example is the problem of data ownership; that "students and teachers remain largely unconscious of the extent and implications of their daily production of digital data traces and trails" (Selwyn 2015, p. 71), which challenge the established traditions in higher education. The issue of learning analytics is particularly important to focus on in future studies since it is a disruption to higher education (Selwyn 2015).

The combination of the two theoretical lenses was beneficial for analysing the empowerment of teachers and students, as well as the tensions within higher education related to the introduction of open textbooks and the threats to students posed by learning analytics. The use of CHAT for analysing the inner power of contradictions, and not only defining their appearance, and at the same time to be able to generalise the results makes CHAT unique (Kaptelinin and Nardi 2006). However, it has to be borne in mind that these findings are based on a very small number of open textbooks' authors and that they not necessarily represent a general view on open textbooks.

The research community needs to expose the implications of involving students and peers in the creation of open textbooks for social justice and democracy, and that this will automatically generate distributed knowledge, relational agency and empowerment which is the most important result of this study.

Acknowledgements Open access funding provided by University of Gothenburg. The authors would like to thank Rajiv Jhangiani for his support and assistance with the selection of the authors and the four text book authors that kindly volunteered to be interviewed. We also want to thank the anonymous reviewers for their constructive comments that greatly contributed to improving the final version of the manuscript.

\section{Compliance with Ethical Standards}

Conflict of interest The author declares that she has no conflict of interest.

Open Access This article is distributed under the terms of the Creative Commons Attribution 4.0 International License (http://creativecommons.org/licenses/by/4.0/), which permits unrestricted use, distribution, and reproduction in any medium, provided you give appropriate credit to the original author(s) and the source, provide a link to the Creative Commons license, and indicate if changes were made. 


\section{Appendix 1}

\section{INTERVIEW GUIDE OPEN TEXTBOOK CREATOR}

\begin{tabular}{|l|l|}
\hline Can you briefly describe your role? & $\begin{array}{l}\text { When you decided to create an OT I guess this was a new learning experience to you? Could } \\
\text { you describe how it all started and the context you are working within? ) }\end{array}$ \\
\hline Do you undertake any education? & Probe to find out what it entails, and whether they think it is useful. \\
\hline
\end{tabular}

\begin{tabular}{|c|c|c|}
\hline & QUESTIONS & PROBE \\
\hline context & $\begin{array}{l}\text { 1. Can you please describe learning situation during } \\
\text { the whole process (we have agreed to explore). } \\
\text { 2. What was the trigger for this learning? }\end{array}$ & \\
\hline \multicolumn{3}{|c|}{ Planning/Forethought } \\
\hline Strategic planning & $\begin{array}{l}\text { 3. How did you define what you needed to learn } \\
\text { 4. To what extent did you plan - or did you just jump right } \\
\text { in? }\end{array}$ & $\begin{array}{l}\text { (probe: What motivated you to learn?) } \\
\text { (probe resources consume) people (connect) } \\
\text { (probe to see if they did any explicit planning, but } \\
\text { try not to mention goals)(create and contribute - } \\
\text { so check if it was for self- or public) }\end{array}$ \\
\hline Goal setting & 5. Did you have a specific outcome in mind? & \multirow{3}{*}{$\begin{array}{l}\text { You are looking for them to describe goals etc. } \\
\text { What incentives did yoou have? Access, } \\
\text { multimedia, collaborative, student } \\
\text { involvement, sprint }\end{array}$} \\
\hline $\begin{array}{l}\text { Occupational } \\
\text { self-efficacy }\end{array}$ & $\begin{array}{l}\text { 6. Did you feel capable of managing your own learning in } \\
\text { this situation? }\end{array}$ & \\
\hline Task interest/value & $\begin{array}{l}\text { 7. Were you interested in learning or merely in solving the } \\
\text { problem? }\end{array}$ & \\
\hline
\end{tabular}

\section{Performance} problem?

\begin{tabular}{|c|c|c|}
\hline \multicolumn{3}{|l|}{ Performance } \\
\hline 'Strategies' & $\begin{array}{l}\text { (we are interested in the particular processes involved in } \\
\text { learning, but ask ...) } \\
\text { 8. How did you learn? } \\
\text { 9. What resources did you utilise? } \\
\text { 10. Did your learning involve the creation of anything - e.g. } \\
\text { did you make notes, or a report for yourself } \\
\text { 11. Would you reuse anything (that they mentioned) again or } \\
\text { was it only of value during the learning process itself? } \\
\text { 12. Did you share anything with anyone else either formally } \\
\text { (e.g. reports) or informally (e.g. through informal } \\
\text { discussions, postings on knowledge bases etc.) } \\
\text { 13. We are interested in the role that technology plays in } \\
\text { learning in the workplace. Did you use your phone } \\
\text { computer etc (probe for software), or make notes on paper } \\
\text { etc. }\end{array}$ & $\begin{array}{l}\text { Probe: a mechanical process or enjoying the } \\
\text { learning process itself }\end{array}$ \\
\hline Help seeking & 14. Who did you interact with during this learning episode & $\begin{array}{l}\text { PEERS, BOSS, STUDENTS, COLLECTIVE } \\
\text { (What strategies did you enact?) } \\
\text { (If not covered)(consume) } \\
\text { (probe for evidence of people at different roles, } \\
\text { expertise levels, and also whether they are } \\
\text { closely related in the academy, or distant (e.g. } \\
\text { evidence of a broader learning network). }\end{array}$ \\
\hline \multicolumn{3}{|l|}{ Self-reflection } \\
\hline Self-evaluation & $\begin{array}{l}\text { 15. Did your actions help you address the problem you had } \\
\text { encountered? } \\
\text { 16. Did you talk to anyone else to discuss the value of the } \\
\text { learning episode (peers/boss/students) } \\
\text { 17. Did you make any personal or formal record reflecting on } \\
\text { your learning? }\end{array}$ & $\begin{array}{l}\text { (probe to see whether they did any self- } \\
\text { evaluation, try to understand to what degree they } \\
\text { evaluated against an external goal.).Try to } \\
\text { establish whether there is any evidence of cyclical } \\
\text { behaviour - did they have to go through } \\
\text { iterations? } \\
\text { (probe: connect). }\end{array}$ \\
\hline Self-satisfaction & 18. Were you satisfied of the overall learning experience? & $\begin{array}{l}\text { Probe: in term of what it impacted your job, team, } \\
\text { organisation }\end{array}$ \\
\hline
\end{tabular}

WRAP-UP

19. Is the learning situation you have described typical of the type of learning you undertake in the workplace?

20. How often do you think you 'learn'?

21. Is there anything else you would like to say with regard to your learning in the workplace?

(capture typical/how this is not typical- e.g approach/motivation, type of problem, type of strategy)

(probe with daily, weekly monthly etc.) Open ended. 


\section{INTERVIEW GUIDE OPEN TEXTBOOK USER}

All of the questions are designed to be answered in relation to the participant's role as an educator.

\section{Context}

1. Do you use other types of OER in your teaching?

- Why do you use these resources?

- How do you use OER?, How frequently do you use OER?

\section{OER and Learning}

2. What role do OER play within your wider professional learning? PROBE:

- How important are OER to your professional learning?

- Do you think that using OER contributes to your professional learning?

3. Do you approach your use of OER with specific aims or goals? FOLLOW UP:

- If yes, what are these aims and goals?

- How well are these aims and goals met by your OER use? Where do you go to find OER?

\section{Specific strategies - questions related to YOUR Open Textbook}

4. Can you briefly describe the Open Textbook you will be focusing on?

5. What role do Open Textbook play in your practice as an educator?

6. How well do Open Textbooks align with your practice needs as an educator?

7. How do you evaluate your use of OpenTextbook for your practice and learning?

8. What do you enjoy most about using your Open Textbook? PROBE:

- What makes it enjoyable?

9. What do you enjoy least about using Open Textbooks? PROBE:

- What makes it less enjoyable?

10. How easy do you think it is to locate your open textbook? PROBE:

- What are the barriers?

- What makes it easier?

11. Do you discuss your use of your Open Textbook with others? FOLLOW UP:

- With whom?

- Why?

12. Do you engage with others when using your Open Textbooks? FOLLOW UP:

- With whom?

- How do you engage?

13. Do you discuss the value of your Open Textbook with others? FOLLOW UP:

- With whom?

- Why do you engage in these discussions?

14. Are there any resources, tools, people or strategies that support your use of OT?

- How do they support your use of your Open Textbook?

15. What knowledge and experience are you drawing on when you use your OT?

- Why is this knowledge or experience useful?

16. Has your use of your Open Textbook changed over time? FOLLOW UP:

- How has your use changed?

17. Have you experienced any changes in your professional practice as a result of your OT use?-

Can you explain what this change has been?

18. What were you hoping to achieve by using this Open Textbook? Did you achieve them?

19. Has learning analytics been valuable? Why? If not - do you plan to use it in the future?

- Which are the risks /problems with learning analytics? 


\section{Appendix 2}

\begin{tabular}{|c|c|c|c|c|}
\hline & Dilemma & Conflict & Critical conflict & Double bind \\
\hline $\begin{array}{l}\text { Type1: } \\
\text { General } \\
\text { conceptual/theo- } \\
\text { retical knowledge }\end{array}$ & $\begin{array}{l}\text { 'Superficially, they [different OT] } \\
\text { may look much alike, but it turned } \\
\text { out that their function and what they } \\
\text { might accomplish are very different. } \\
\text { What should it look like?... Nothing } \\
\text { flashy. But some are more complex, } \\
\text { and you have to find that balance } \\
\text { between user-friendliness and } \\
\text { effectiveness.' }\end{array}$ & $\begin{array}{l}\text { 'I also was fairly critical before I } \\
\text { started. I was very concerned about } \\
\text { the quality. I was concerned that } \\
\text { they [the OT] came from basically } \\
\text { computer scientists' view [sic] on } \\
\text { what openness means rather than on } \\
\text { a pedagogical view on what } \\
\text { openness means.' }\end{array}$ & & \\
\hline $\begin{array}{l}\text { Type 2: } \\
\text { Context specific } \\
\text { conceptual/theo- } \\
\text { retical knowledge }\end{array}$ & $\begin{array}{l}\text { 'Textbooks in history ... It's } \\
\text { memory about here is the story line, } \\
\text { here is the meta narrative ... but } \\
\text { they don't necessarily talk about the } \\
\text { doing of history. But we are actually } \\
\text { more interested in the doing of } \\
\text { history. They [students] want to } \\
\text { learn more! ... Why are students } \\
\text { going down these blind alleys? They } \\
\text { are absorbing all this material, but } \\
\text { they are not connecting to anything!' }\end{array}$ & & $\begin{array}{l}\text { 'I did go back to that professor, and I } \\
\text { asked him to do a formal review. And } \\
\text { I got XX to do a formal review, and I } \\
\text { got YY to do a review, and I } \\
\text { published the reviews in the back of } \\
\text { the book. I felt that every review was } \\
\text { very important. And obviously it is } \\
\text { not independent in the way a } \\
\text { publisher would go, but it might be } \\
\text { better to have BCcampus to pick the } \\
\text { reviewers rather than me picking } \\
\text { them.' }\end{array}$ & \\
\hline $\begin{array}{l}\text { Type 3: } \\
\text { Practical/experie } \\
\text { ntial knowledge }\end{array}$ & $\begin{array}{l}\text { 'Yeah, it's hard to know how widely } \\
\text { it has been accessed ... They just } \\
\text { access it, go to the classroom, this is } \\
\text { the URL, that's the textbook. There } \\
\text { is no lining up at the book store or } \\
\text { that nonsense, so that's great. But it } \\
\text { means that we are not aware where } \\
\text { it's being used except for those } \\
\text { instructors who have been kind } \\
\text { enough to have been in touch with us } \\
\text { while they have been using that.' }\end{array}$ & $\begin{array}{l}\text { 'My students all work on their own } \\
\text { websites, and they aggregate their } \\
\text { own data of their posting stuff. We } \\
\text { have done some preliminary work } \\
\text { [on LA] like trying to understand } \\
\text { what data is useful to students: if the } \\
\text { data lives with them rather than with } \\
\text { the LMS.' }\end{array}$ & $\begin{array}{l}\text { 'In general, lots of faculty like me } \\
\text { are making things like this that are } \\
\text { awesome, but you will never find it, } \\
\text { which is unfortunate... If you hook } \\
\text { up with a place with discoverability, } \\
\text { they can help with storage, with } \\
\text { organization. So, I have some hope it } \\
\text { will get better. But in general, it was } \\
\text { just living on Pressbooks, and you } \\
\text { would probably never find it if it } \\
\text { wasn't for the press that came out } \\
\text { about it.'. }\end{array}$ & $\begin{array}{l}\text { 'The fact that we could get a prettier } \\
\text { chapter that is more sophisticated, } \\
\text { more articulated is not that } \\
\text { important, but that we are getting the } \\
\text { same content and they [the students] } \\
\text { are getting this pedagogical } \\
\text { experience is much more helpful to } \\
\text { learning, I think. Sometimes content } \\
\text { is number one of what your students } \\
\text { need. But for me, sometimes, it's } \\
\text { number two. And the experience of } \\
\text { the building [of knowledge] is } \\
\text { actually more valuable than the } \\
\text { specifics of that content.' }\end{array}$ \\
\hline $\begin{array}{l}\text { Type 4: } \\
\text { Self-regulative } \\
\text { knowledge }\end{array}$ & $\begin{array}{l}\text { "The way that I frame the textbook is } \\
\text { important. I think it is important for } \\
\text { the students and for me to be very } \\
\text { clear that this is an OT, this is why } \\
\text { we are using it: you save money and } \\
\text { we can build these things in the } \\
\text { course etc. etc. I think the students } \\
\text { build a better relationship with me. } \\
\text { Not just walking into the classroom } \\
\text { and saying this is our textbook.' }\end{array}$ & & $\begin{array}{l}\text { 'Also, links to proprietary software is } \\
\text { [sic] an issue. I think if you have an } \\
\text { open textbook, you should as much } \\
\text { as possible use open source.' }\end{array}$ & $\begin{array}{l}\text { 'We need to know a lot more about } \\
\text { how the algorithms are written: what } \\
\text { kind of decisions are being embedded } \\
\text { in those algorithms. The obvious } \\
\text { example is that they are using LA to } \\
\text { predict students' success before they } \\
\text { enroll. My worries [sic] is that they } \\
\text { are going to screen out all the } \\
\text { students who they feel don't have a } \\
\text { chance of surviving. And what kind } \\
\text { of education policy is that?? }\end{array}$ \\
\hline $\begin{array}{l}\text { Type 5: } \\
\text { Socio-cultural } \\
\text { knowledge } \\
\text { (community- } \\
\text { based) }\end{array}$ & $\begin{array}{l}\text {... I think that other than that, it is } \\
\text { taking a step away from some of the } \\
\text { really amazing student activism that } \\
\text { happened here. I do think students } \\
\text { realize that knowledge is not coming } \\
\text { from a closed resource but something } \\
\text { that we as a community can build and } \\
\text { build better ... I think they have a } \\
\text { better idea of collaborate [sic] } \\
\text { approaches, and now, I'm just } \\
\text { blinded by working with great } \\
\text { students. I think they understand that } \\
\text { they can build better together, } \\
\text { whereas I think my generation, or } \\
\text { maybe the one before me, was really } \\
\text { focused on the individual } \\
\text { contribution." }\end{array}$ & $\begin{array}{l}\text { 'I always felt the OER movement } \\
\text { showed the limitation of general open } \\
\text { access to education, particularly in } \\
\text { the US, which you know is very } \\
\text { much dominated by private or } \\
\text { commercial education, whereas in the } \\
\text { UK, it was a pedagogical thing We } \\
\text { wanted everybody to have access to } \\
\text { higher education, which is a much } \\
\text { broader definition!' }\end{array}$ & $\begin{array}{l}\text { 'Student says this is the narrative by } \\
\text { XX, but it's not only his voice. There } \\
\text { are many voices, and the instructor } \\
\text { should feel confident to add their } \\
\text { own voice if they want to add their } \\
\text { own stuff or wanna challenge what } \\
\text { somebody is saying. They can do } \\
\text { that. They can engage in the debate, } \\
\text { and they can actually imbed students' } \\
\text { debates in the textbook ... But once } \\
\text { the textbook is out there, there will be } \\
\text { hundreds of } 2.0 \text { versions of the } \\
\text { textbook... So, I see it very much as } \\
\text { a dynamic learning tool ... That's the } \\
\text { more exciting part of that. It's not } \\
\text { what I have been writing.' }\end{array}$ & $\begin{array}{l}\text { "So, I've had a couple of translators } \\
\text { who didn't want to put it up as a } \\
\text { digital book. They just wanted to } \\
\text { print the book and give it away, but } \\
\text { they wouldn't put it on a URL to } \\
\text { make it accessible for everybody. So, } \\
\text { I had to talk to XX and write a CC } \\
\text { license on non-commercialize, which } \\
\text { means they can't sell the book they } \\
\text { have translated. If they print it, they } \\
\text { can charge the cost, but they can't } \\
\text { make a profit on it. And I have had a } \\
\text { big problem with the Chinese. They } \\
\text { wanted to get a commercial publisher } \\
\text { to do the translation, and I said that's } \\
\text { alright if they are willing to give the } \\
\text { book away for free. I was finding I } \\
\text { couldn't control these people. That's } \\
\text { the problem that you can't control. } \\
\text { On the other hand, arguing for the } \\
\text { license echoes.' }\end{array}$ \\
\hline $\begin{array}{l}\text { Type 6: } \\
\text { Socio-cultural } \\
\text { knowledge } \\
\text { (workplace- } \\
\text { based) }\end{array}$ & $\begin{array}{l}\text { 'My worries are so often that I go to } \\
\text { universities and talk about new } \\
\text { technologies, and } 90 \% \text { of time, I'm } \\
\text { preaching to the converted. I'm } \\
\text { talking to either instructional } \\
\text { designers or people working in } \\
\text { technology units, and that teachers } \\
\text { working in faculties not working } \\
\text { online don't come to my lectures. } \\
\text { OK. I wanted to get to that group. I } \\
\text { wanted to push it wider, and I felt } \\
\text { that an open textbook where they } \\
\text { could just click and have a look. The } \\
\text { front page is really good. I mean, } \\
\text { going into the open textbook, what } \\
\text { comes up is the list of content and } \\
\text { that you can click on any of those: it } \\
\text { opens up the chapters. So, in } 30 \\
\text { seconds, they get a fecling, and if } \\
\text { interested, they will carry on. It } \\
\text { should be something that is really } \\
\text { accessible. I mean, shouldn't have to } \\
\text { do much to get hooked.' }\end{array}$ & $\begin{array}{l}\text { 'We had a long discussion about the } \\
\text { comment facilities. What I did was } \\
\text { that I created activities at the end of } \\
\text { each chapter, and I wanted students } \\
\text { to do the activities and respond in the } \\
\text { comments. Now, BCcampus wasn't } \\
\text { too happy with that initiative because } \\
\text { they said was that if this is gonna be } \\
\text { picked up and adapted, then different } \\
\text { professors would want their own } \\
\text { students to have their own comment } \\
\text { box, and if you have one for the } \\
\text { whole book, then ... I argued against } \\
\text { that, and I said, "Well ... there will } \\
\text { be lots of people just reading the } \\
\text { book on their own. They are not in a } \\
\text { class, and there should be a space for } \\
\text { them as well." And, incidentally, I } \\
\text { found about } 3 \text { months ago that he } \\
\text { actually has taken this out. I think } \\
\text { they were all worried about the traffic } \\
\text { they were getting. Either you have to } \\
\text { answer ... }\end{array}$ & $\begin{array}{l}\text { 'Students were super excited that the } \\
\text { book was free, but they weren't } \\
\text { excited when they started using it } \\
\text { because it lacked a lot additional } \\
\text { material that they were used to - like } \\
\text { illustrations, maps and instructions, } \\
\text { particularly introductions. So that } \\
\text { was when we started to use the } \\
\text { current students in the course to build } \\
\text { out the textbook with the things that } \\
\text { they found were missing, and they } \\
\text { got really excited about contributing } \\
\text { to a book ... So, what started out as a } \\
\text { cost replacement model ended up } \\
\text { being much more a pedagogic } \\
\text { success story. So, we did save cash, } \\
\text { but we also really had a library } \\
\text { course where students contributed to } \\
\text { a book. }\end{array}$ & \\
\hline
\end{tabular}




\section{References}

Arinto, P. B., Hodgkinson-Williams, C., King, T., Cartmill, T., \& Willmers, M. (2017). Research on open educational resources for development in the global south: project landscape. In C. Hodgkinson-Williams \& P. B. Arinto (Eds.), Adoption and impact of OER in the global South (pp. 3-26). https://doi. org/10.5281/zenodo.1038980.

Baker, J., \& Hood, J. (2011). Things you should know about Gosling Publishing. Retrieved May 2018 http:// affordablelearningok.org/uploads/WH/Q4/WHQ4xTVjvdCxIixua3oHVw/Educause-Open-Textbook7-things.pdf.

Bliss, T. J. (2017). Why we fund open textbooks (and plan to do more). Retrieved May 2018 http://www. hewlett.org/why-we-fund-open-textbooks-and-plan-to-do-more/.

Camilleri, A., Ehlers, U., \& Pawlowski, J. (2014). State of the art review of quality issues related to open educational resources (OER). Luxembourgh: Publication Office of the European Union, 1-52. Retrieved May 2018 http://www.pedocs.de/volltexte/2014/9101/.

Chatti, M. A., Muslim, A., \& Schroeder, U. (2017). Toward an open learning analytics ecosystem. In B. K. Daniel (Ed.), Big data and learning analytics in higher education (pp. 195-219). Cham: Springer International Publishing.

Ecorys \& Bertelsmann Stiftung. (2015). Adult learners in digital learning environments. European Commission Directorate-General for Employment, Social Affairs and Inclusion Report. Luxembourg: Publications Office of the European Union.

Edwards, A. (2010). Being an expert professional practitioner: The relational turn in expertise (Vol. 3). Dordrecht: Springer.

Engeström, Y. (1987). Learning by expanding: An activity-theoretical approach to developmental research. Diss. Helsinki: Univ.

Engeström, Y., \& Sannino, A. (2010). Studies of expansive learning: Foundations, findings and future challenges. Educational Research Review, 5(1), 1-24.

Engeström, Y., \& Sannino, A. (2011). Discursive manifestations of contradictions in organizational change efforts: A methodological framework. Journal of Organizational Change Management, 24(3), 368-387.

European Commission. (2013). Opening up education: Innovative teaching and learning for all through new technologies and open educational resources. Communication 341. Accessed Retrieved 2018 http://ec.europa.eu/transparency/regdoc/rep/1/2013/EN/1-2013-654-EN-F1-1.Pdf.

Farrow, R. (2017). Open education and critical pedagogy. Learning, Media and Technology, 42(2), 130146. https://doi.org/10.1080/17439884.2016.1113991.

Fontana, R. P., Milligan, C., Littlejohn, A., \& Margaryan, A. (2015). Measuring self-regulated learning in the workplace. International Journal of Training and Development, 19(1), 32-52.

Freire, P. (2000). Pedagogy of the oppressed. New York: Bloomsbury Academic.

Hood, N., \& Littlejohn, A. (2017). Knowledge typologies for professional learning: educators' (re)generation of knowledge when learning open educational practice. Educational Technology Research and Development, 65(6), 1583-1604.

Iiyoshi, T., \& Kumar, M. S. V. (2008). Opening up education. The collective advancement of education through open technology, open content, and open knowledge. Cambridge, MA: MIT Press.

Jhangiani, R. S., Pitt, R., Hendricks, C., Key, J., \& Lalonde, C. (2016). Exploring faculty use of open educational resources at British Columbia post-secondary institutions. BCcampus Research Report. Victoria, BC: BCcampus. Retrieved May 2018 https://bccampus.ca/files/2016/01/BCFacultyUseOfO ER_final.pdf.

Johnson, L., Levine, A., Smith, R., \& Stone, S. (2010). Horizon report for the new media consortium and the EDUCAUSE learning initiative. Retrieved May 2018 https://files.eric.ed.gov/fulltext/ED510220. pdf.

Kaatrakoski, H., Littlejohn, A., \& Hood, N. (2017). Learning challenges in higher education: an analysis of contradictions within open educational practice. Higher Education, 74(4), 599-615.

Kanwar, A., Balasubramanian, K., \& Umar, A. (2010). Towards sustainable open education resources: A perspective from the global south. American Journal of Distance Education, 24(2), 65-80.

Kaptelinin, V., \& Nardi, B. (Eds.). (2006). Acting with technology: Activity theory and interaction design. Cambridge, MA: MIT Press.

Karunanayaka, S. P., \& Naidu, S. (2018). Designing capacity building of educators in open educational resources integration leads to transformational change. Distance Education, 39(1), 87-109.

Kress, G. (2009). Multimodality: A social semiotic approach to contemporary communication. London: Routledge. 
Latour, B. (2005). Reassembling the social: An introduction to actor-network-theory. Oxford, UK: Oxford University Press.

McAndrew, P., \& Farrow, R. (2013). Open educational research: From the practical to the theoretical. In R. McGreal, W. Kinuthia, \& S. Marshall (Eds.), Open educational resources: Innovation, research and practice. Commonwealth of Learning and Athabasca University: Vancouver.

Pardo, A., \& Siemens, G. (2014). Ethical and privacy principles for learning analytics. British Journal of Educational Technology, 45(3), 438-450.

Säljö, R. (2012). Literacy, digital literacy and epistemic practices: The co-evolution of hybrid minds and external memory systems. Nordic Journal of Digital Literacy, 7(1), 5-19.

Selwyn, N. (2015). Data entry: Towards the critical study of digital data and education. Learning, Media and Technology, 40(1), 64-82.

Van Leeuwen, A., Janssen, J., Erkens, G., \& Brekelmans, M. (2015). Teacher regulation of cognitive activities during student collaboration: Effects of learning analytics. Computers \& Education, 90, 80-94.

Wiley, D., Hilton, J., Ellington, S., \& Hall, T. (2012). A preliminary examination of the cost savings and learning impacts of using open textbooks in high school science classes. International Review of Research in Open and Distance Learning, 13(3), 261-276.

Zimmerman, B. J. (2000). Attaining self-regulation: A social cognitive perspective. In M. Boekaerts \& P. R. Pintrich (Eds.), Handbook of self-regulation (pp. 13-39). San Diego, CA: Academic Press.

Publisher's Note Springer Nature remains neutral with regard to jurisdictional claims in published maps and institutional affiliations. 